\title{
Management of blue gum eucalyptus in California requires region-specific consideration
}

\author{
by Kristina M. Wolf and Joseph M. DiTomaso
}

Blue gum eucalyptus (Eucalyptus globulus) is a large tree native to Australia that was widely planted throughout California for reforestation, building and timber, but in some areas has spread beyond its planted borders and substantially altered wildlands. Due to its fast growth, large size and reproductive potential, blue gum's impacts on native vegetation, wildlife and ecosystem processes are of concern, particularly in areas with reliable year-round rainfall or fog, where it is most likely to spread. Depending on levels of invasion and rate of spread, blue gum may have negative, positive or neutral impacts on fire regimes, water and nutrient availability, understory vegetation and higher trophic levels. Additional research on the abiotic and biotic impacts of blue gum, quantitative estimates of area covered by blue gum, and weed risk assessments that allow for region-specific climatic information and management goals to be incorporated are needed to guide management of blue gum populations.

$\mathrm{F}$ Tor many Californians, eucalypts (Eucalyptus spp.) are a valued part of the natural landscape, while for others, they are a nightmare that fueled the disastrous 1991 Oakland hills fire that claimed 25 lives (NPS 2006). Introduced to California from Australia circa 1856 (Esser 1993), Eucalyptus globulus Labill. (blue gum eucalyptus, hereafter "blue gum") was the most widely planted species within the genus, and mainly occurs in grasslands and some previously forested areas. About 40,000 acres ( $>16,000$ hectares) of blue gum were planted in California between 1856 and the 1930s (Butterfield 1935), extending from Humboldt County in the north to San Diego County in the south, with best individual growth and survival occurring in the coastal fog belt in the vicinity of San Francisco (Burns and Honkala 1990). Herbarium collections today show blue gum occurrences in at least 23 counties (UC Regents 2014).

However, blue gum has naturalized (escaped from its original plantings into wild areas) in some parts of California (Esser 1993; Ritter and Yost 2009). And, in some areas, invasive populations those that have naturalized and cause economic or ecological harm - have so altered landscapes and ecosystem processes that the impacts raise many ecological, social and cultural questions. For example, should blue gum be retained as overwintering habitat for monarch butterflies (Danaus plexippus L.), whose populations have dropped by an estimated $90 \%$ due to declines in suitable habitat (Griffiths and Villablanca 2013)? Should we perhaps plant even more? Or should these "weeds" (i.e., plants out of place) be removed? While an often contentious subject with proponents on both sides (Jones 2009), it is important to consider the pros and cons when making decisions regarding management of blue gum (LSA Associates 2009).

Online: http://californiaagriculture.ucanr.edu/ landingpage. $\mathrm{cfm}$ ?article $=$ ca.v070n01p39\&fulltext=yes doi: 10.3733/ca.v070n01p39 
Our objectives are to (1) summarize the traits of blue gum that may contribute to invasiveness and identify factors contributing to spread, (2) describe biotic and abiotic impacts of nonnative blue gum in California, (3) describe current trends in the spread, removal and introduction of blue gum in California, and (4) clarify research needs and management implications regarding blue gum presence and invasiveness.

\section{Literature review methods}

Because much information regarding the biotic and abiotic impacts of blue gum exists in the non-peer-reviewed literature, including agency reports, blogs and personal observations by land managers, this paper is not a systematic review of the scientific literature. Limiting our search to peer-reviewed scientific literature could result in the omission of critical information on the general status of blue gum and research needs. Rather, we obtained information via scientific database searches (including Web of Science, Google Scholar and AGRICOLA), general Internet searches, and solicitation of information regarding invasions (or lack thereof) and management via emails and phone calls to professionals working in landscapes containing blue gum (including California State Parks, California Invasive Plant Council, California Polytechnic State University San Luis Obispo, UC Berkeley and UC Davis).

\section{Origin and characteristics}

Blue gum, a large tree in the Myrtle family (Myrtaceae) that is native to southeastern Australia (UC Regents 2014), is the most extensively planted Eucalyptus species in the world (Burns and Honkala 1990). Trees can grow to 180 feet (55 meters [m]) tall with bark that sheds in long strips, leaving smooth surfaces of contrasting colors (Farmer 2013; Skolmen 1983). Mature leaves are a waxy grey-blue-green and sickle shaped, while young leaves are oval shaped and bluish green, with distinctive square stems (Brooker 2000). The species has a wide range of climatic adaptability, with the most successful introductions in mild, temperate climates, or cool, high elevations in tropical areas. Ideal climates for establishment and growth have no severe dry season, mean annual rainfall of 35 inches ( 90 centimeters) and a minimum temperature above $20^{\circ} \mathrm{F}\left(-7^{\circ} \mathrm{C}\right)$ at all times.

In the United States, blue gum is present in Hawaii (National Tropical Botanical Garden 2015) and California, where it has naturalized (Baldwin 2012). Its fast growth, large size and ability to thrive in California's Mediterranean climate made it an attractive choice for building, furniture, firewood, medicinal uses, cleaning products and, originally, reforestation and afforestation efforts. Many naturalists, scientists and government agencies extoled its merits, recommending the species for large-scale planting, even offering awards for individuals who planted the largest number of trees (Farmer 2013; Santos 1997).

However, after planting millions of trees, lumber production intended for railroad ties was abandoned because blue gum wood often split, twisted and cracked. Further, the wood could not be treated properly for lumber or furniture (Groenendaal 1983). However, this did not prevent ardent supporters from recommending it for other uses, including ornamental plantings, windbreaks, shade, medicinal purposes, firewood and anticipated environmental benefits such as reductions in soil erosion. As a result, blue gum plantations continued to persist in California (Farmer 2013).

Some plantings exhibit invasive characteristics and environmental impacts that contributed to an initial "moderate" invasive status by the California Invasive Plant Council (Cal-IPC), although these have been poorly documented in the scientific literature. Opposing views of blue gum's invasive potential have sparked heated debate in recent decades, and in 2015 , its status was reexamined in response to a request from stakeholders for another review. The reassessment of the available ecological evidence resulted in Cal-IPC downgrading blue gum's invasive status to "limited" (Cal-IPC 2015)

According to the Cal-IPC criteria, a limited invasive status is either due to a species that is widespread, but does not cause significant negative impact, or a species that is widespread, but causes significant ecological impacts in specific regions or areas of the state, yet minimal or no impact in other areas. Cal-IPC found that blue gum's limited status corresponds to the latter category, where significant negative ecological impacts occur in limited areas along the California coast.

\section{Reproductive traits and dispersal}

Reproductive traits. Depending on the region and climatic conditions, certain reproductive traits can be significant contributors to the invasiveness of a plant, such as asexual reproduction and the production of a high number of propagules (Radosevich et al. 2007). Reproductive traits that could contribute to blue gum's ability to spread include yearly seed production (in many areas), seed production for more than 3 months per year (November to April, in California) and a tendency to resprout prolifically after damage (e.g., cutting, fire) (Rejmánek and Richardson 2011).

In California, blue gum produces flowers during the wet season, generally from November to April, and the fruit (a distinctive top-shaped woody capsule, 15 millimeters long and 2 centimeters wide) ripens between October and March. Although many sources indicate prolific seed production at 3- to 5-year intervals, these "heavy seed crops" have not been verified in the scientific literature. The seeds of blue gum are very small, with an average weight of just over 2 milligrams per seed (460 seeds/gram) (Burns and Honkala 1990). However, little is known about what fraction of blue gum seeds are viable.

While blue gum might produce abundant seed, it does not generally find appropriate conditions for germination. As such, it does not often encroach into treeless areas without purposeful cultivation. Germination rates are typically very low under natural conditions, ranging from a high success rate of $1 \%$ to the more typical low of $0.1 \%$ (Bean and Russo 2014). Seed germination is highest on bare mineral soil (Bean and Russo 1989), particularly under high light conditions, such as after logging or fire (Burns and Honkala 1990).

Germination within dense plantations is even less common (Bean and Russo 1989). Blue gum produces a thick litter layer and allelochemicals (natural substances produced by plants that can suppress growth), which may inhibit not only its own germination, but also that of other plants (Molina et al. 1991; Watson 2000). Despite this, establishment of blue gum in undisturbed forests and scrub has been observed repeatedly in coastal areas of 
California (Cal-IPC 2015), and young trees can produce seeds within 2 to 5 years of germination, although not in great quantities (Burns and Honkala 1990; Metcalf 1924). Seeds in the soil under natural conditions probably remain viable less than a year (Rejmánek and Richardson 2011).

Vegetative reproduction can also contribute to invasive potential, making control or removal difficult. Blue gum sprouts readily from stumps of all sizes and ages, as well as from the lignotuber (woody swelling of the root crown at or below ground level) and roots. Blue gum lignotubers can survive for many years in the soil after stems die back (Esser 1993; Skolmen 1983). If a tree is cut down, lignotubers become active and each bud may produce many new shoots, commonly known as "sucker growth" or coppice shoots (Bean and Russo 2014; Davidson 1993), which may be even more vigorous and difficult to control than the original growth (Farmer 2013). Resprouting is common after fire or cutting, but is not a primary mode of spread. Although reproduction can also occur when new shoots arise from roots/rhizomes (Esser 1993), this has rarely been noted in the literature, even in repeatedly harvested stands of blue gum (Skolmen 1983).

Dispersal. Most blue gum seeds are not dispersed long distances and are generally distributed by wind and gravity. In one study, the fruit capsules were calculated to disperse only 66 feet $(20 \mathrm{~m})$ from a 131-foot $(40 \mathrm{~m})$ tree height with winds of 6 miles/hour (10 kilometers/ hour) (Burns and Honkala 1990). On occasion, blue gum seeds can be dispersed long distances by water when growing near streams or rivers. The lack of a longdistance dispersal mechanism would account for the relatively slow, if any, rate of spread (Rejmánek and Richardson 2011), although rate of spread across the state has not been rigorously documented in experimental or observational evidence.

\section{Potential impacts of blue gum}

Potential risks and impacts can be grouped into two categories - abiotic and biotic - that may work independently or interact to produce blue gum impacts on ecosystem processes.

\section{Abiotic impacts.}

Fire regime changes and fire hazards. Blue gum was most frequently planted in

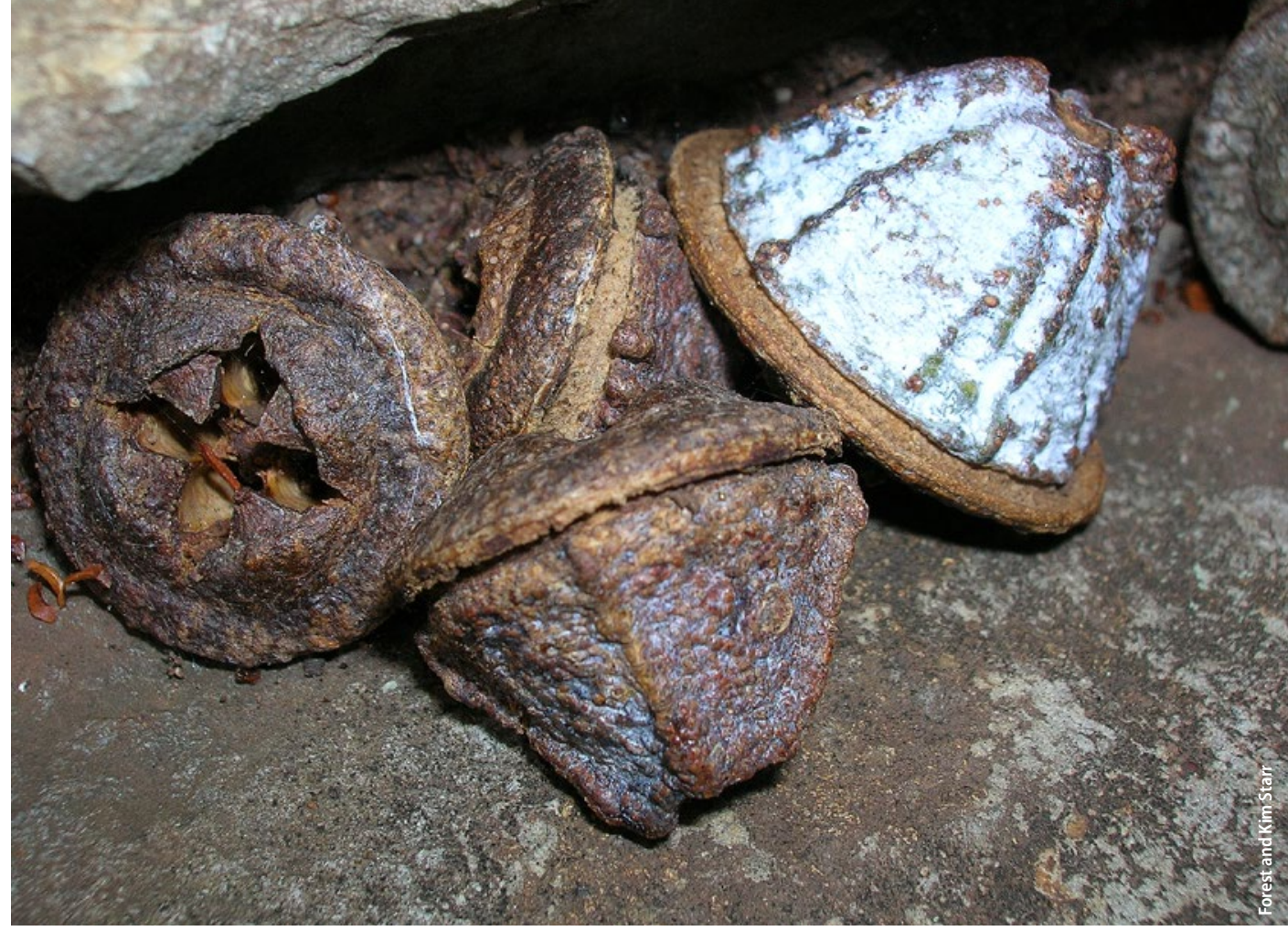

Blue gum eucalyptus trees can produce a large quantity of seeds in woody capsules, but germination rates are generally low.

grasslands, although some plantings occurred in, or later escaped into, native tree stands (Griffiths and Villablanca 2013). Because of the dramatic shift in plant communities (e.g., from grasslands to tree plantations), it is not unexpected that the historic fire intensity and frequency (i.e., the natural fire regime) were also dramatically altered (Bossard et al. 2000; FEMA 2013; LSA Associates 2009; Russell and McBride 2002). As a consequence, vegetation management plans in blue gumdominated communities should consider historic fire regimes, goals for fire risk management and potential hazards to adjacent businesses and homes.

In Australia, Dickinson and Kirkpatrick (1985) found that live blue gum leaves were resistant to combustion, but dead leaves were highly flammable and the most energy-rich component of the tree. Juvenile and adult leaves of blue gum had intermediate flammability in comparison to other species evaluated. They concluded that living blue gum trees and fuel components within litter had the greatest tendency to propagate fires relative to species from wet sclerophyll (high moisture, low light, dense eucalyptus forests) and gully habitats or Casuarina dry forest communities.

Species that produce oily resins, such as blue gum, are far more ignitable than those that do not. On a scale of 1 to 10 for ignition potential, with 1 representing species most easy to ignite and 10 most difficult, blue gum scored 1 to 2 (very high ignition potential). For comparison, oak/bay woodland received a score of 6 to 8 , redwood 8 , scrub vegetation 4 to 8 , and annual grassland vegetation 1 to 3 (LSA Associates 2009).

In the 2013 environmental impact statement for the FEMA Hazardous Fire Reduction grant in the East Bay hills of California, blue gum flame lengths (used as a proxy for flammability) were estimated at 6 to 21 feet (1.8 to $6.4 \mathrm{~m}$ ); in comparison, flame length for oak/bay woodland was 1 to 34 feet (0.3 to $10.4 \mathrm{~m}$ ), Monterey pine (Pinus radiata D. Don) 1 to 6 feet $(0.6$ to $4.9 \mathrm{~m})$, coastal redwood (Sequoia sempervirens (Lamb. ex D. Don) Endl.) 7 to 31 feet (2.1 to $9.4 \mathrm{~m})$, northern coastal scrub 14 to 32 feet ( 4.3 to $9.8 \mathrm{~m}$ ) and nonnative grasslands 2 to 10 feet (0.6 to $3.0 \mathrm{~m}$ ). Flame lengths in young blue gum plantations range from 7 to 31 feet (2.1 to $9.4 \mathrm{~m}$ ), depending on fuel volumes, stand structure, treatment history and slope (FEMA 2013).

In addition to being generally more ignitable and highly flammable in comparison with some species, blue gum accumulates more fuel for wildfires than grasslands and native tree species. Blue gum can accumulate 68,000 pounds per acre (lb/ac) of dropped limbs, bark and leaves (76,000 kilograms/hectare [kg/ha]), compared to $42,000 \mathrm{lb} / \mathrm{ac}(47,000 \mathrm{~kg} / \mathrm{ha})$ for California bay (Umbellularia californica (Hook. and Arn.) Nutt.) and 26,000 lb/ac 
allelopathic properties of blue gum in the Mediterranean (Spain). Additional research is needed to clarify the naturally occurring allelopathic potential of blue gum.

Changes to hydrology. Despite its ability to withstand prolonged dry summers (Florence 1996; Pryor 1976), blue gum is not particularly drought tolerant (USDA PLANTS 2015), and is only able to survive by tapping into deep water reservoirs and transpiring freely (DiTomaso and Healy 2007), which can alter water availability to depths of 45 feet $(14 \mathrm{~m})$ and distances of 100 feet $(30 \mathrm{~m})$ from the trunk. While blue gum does not economize in the use of water, it has deep and extensive root systems and can extract water from the soil at higher soil moisture tensions than most mesophytic (terrestrial plants that are not adapted to very wet or very dry conditions) plants (Florence 1996; Pryor 1976). This allows blue gum to compete strongly with other vegetation for water (HEAR 2007).

Compared with conifers, blue gum uses less water per unit of biomass, but blue gum's high biomass production, even under low rainfall conditions, may reduce nearby streamflows more rapidly than other slower-growing tree species (Davidson 1993). Thus, in dry areas the benefits of lower water use per unit biomass of blue gum may be outweighed by impacts on soil moisture content due to high total water consumption (Rejmánek and Richardson 2011).

In support of this finding, Williams (2002) noted that streambeds became eroded and dewatered near blue gum plantations. Potential allelopathic effects on the germination and cover of understory species in combination with the high water use capacity of blue gum may also result in a greater risk of erosion in hillsides covered by blue gum (HEAR 2007). Davidson (1993) also implicated non-wettability of soils (water repellence and hydrophobicity due to blue gum oils deposited on soil particles) as a contributing factor to low understory cover, which may alter erosion rates. However, research that more clearly elucidates the impacts of blue gum plantations on hydrology and erosive processes is necessary.

Changes to nutrient cycles and light availability. Leaves and branches of blue gum have been noted to decompose very slowly (DiTomaso and Healy 2007), which can alter nutrient dynamics and germination, emergence and growth of seedlings. Consistent with this, Aggangan et al. (1999) reported a reduction in nitrogen mineralization rates in soil below blue gum litter. However, in a riparian area, Lacan et al. (2010) found no difference in litter breakdown between blue gum and native vegetation.

Blue gum shading reduces light availability and might create conditions that inhibit the growth of seedlings and most other plants in the understory (DiTomaso and Healy 2007). While native trees growing in crowded conditions also shade understory plants, the combination of a thick litter layer and potential allelopathy may exacerbate the effects of blue gum shading (Bossard et al. 2000). Moreover, blue gum alters light availability in otherwise open grasslands and within invaded native forests, which could interfere with the germination and growth of some plant species (Peter Warner, Botanical and Ecological Consulting, personal observation as listed on original Cal-IPC assessment form, 2004).

In general, while some evidence is observational, or additional research is needed to clarify the abiotic environmental impacts, blue gum appears to alter historical abiotic conditions and ecosystem processes not only where it is planted, but also in natural areas to which it has spread. In some cases, these impacts are severe, hazardous or ecologically irreversible (Cal-IPC 2003).

\section{Biotic impacts.}

Changes to plant community dynamics. While blue gum stands are often monocultures (in terms of tree cover), this is not necessarily due to competitive exclusion of native trees - it could be that they were purposefully planted at high densities. Some sources indicate that blue gum outcompetes native vegetation as it naturalizes in mesic areas (see review by Griffiths and Villablanca 2013), but experiments have not been conducted to confirm this. However, in both planted and invaded areas, blue gum stands can form near monotypic canopy covers, particularly in coastal ecosystems (Cal-IPC 2015). Ritter and Yost (2012) sampled 52 unique stands of blue gum in coastal regions of California. Of these stands, 21 had not naturalized at all, 11 had extensive naturalization, and the remainder were somewhere in between. Sampled areas where naturalization was documented included riparian corridors and sites along the coast from Monterey Bay north, where summer fog provides sufficient water in an otherwise long, dry summer season.

Blue gum plantings in grasslands represent a dramatic change to community composition from open grassland to forest. In grasslands supporting livestock and native ungulates, blue gum has a considerable competitive advantage as compared with many other tree species, as its juvenile foliage is seldom browsed by cattle or sheep (its unpalatability may be related to its moderate toxicity rating [CPCS 2009]). This condition not only contributed to its popularity for planting in open grasslands years ago, but also permits newly recruited seedlings outside planted stands to survive in the presence of grazing animals (Burns and Honkala 1990).

Reports on the impact of blue gum stands on plant diversity are variable, with some observations noting the presence of several native species supported in the understory (LSA Associates 2009). While native plants may be found beneath blue gum trees at some locations in California (CAPRC 2011), evidence regarding the relative amounts of native cover and trends in native vegetation is minimal. However, most reports indicate that vegetation is "sparse" under blue gum stands (Bean and Russo 2014; DiTomaso and Healy 2007; Esser 1993), which may be due to the combined effects of competition for water, tree density and shading, allelopathy, non-wettability of soils and a thick inhibitory litter layer. For example, at Mount Davidson in San Francisco, only $36 \%$ of the blue gum understory is native, with 29 of 50 species recorded as nonnative (SFRP 2006). Even other rapidly growing nonnative trees may have difficulty persisting in blue gum plantations: Metcalf (1924) reported that Lombardy poplar (Populus nigra L.) planted among blue gum only persisted for 15 to 20 years before it was overtopped by blue gum.

Without removal of blue gum, plant community composition is not likely to support historic community composition. Even with removal, treatments must be repeated multiple times due to resprouting or new flushes of blue gum seedlings (LSA Associates 2009), resulting in continued disturbance and 
potentially detrimental impacts on community composition for several years. For example, Davidson (1993) points out that following blue gum removal, soils may be persistently non-wettable due to the oils deposited by blue gum. This could further affect remaining vegetation through detrimental impacts on water infiltration and runoff. Therefore, the potentially negative impacts of blue gum removal and longterm management should be carefully considered when developing a management plan.

Impacts on higher trophic levels. Impacts of blue gum on terrestrial vertebrates are mixed, with some reports indicating significantly lower species diversity of arthropods, small mammals and birds in blue gum stands (Cal-IPC 2015; Rejmánek and Richardson 2011). For example, in Angel Island State Park (San Francisco Bay), 41 species of birds were observed in native vegetation, but only 30 species in blue gum stands. However, approximately three times more California slender salamanders (Batrachoseps attenuatus) were found in blue gum vegetation than in native forests (Rejmánek and Richardson

Oils and resins in leaves may increase flammability of blue gum and contribute to non-wettability of soils.

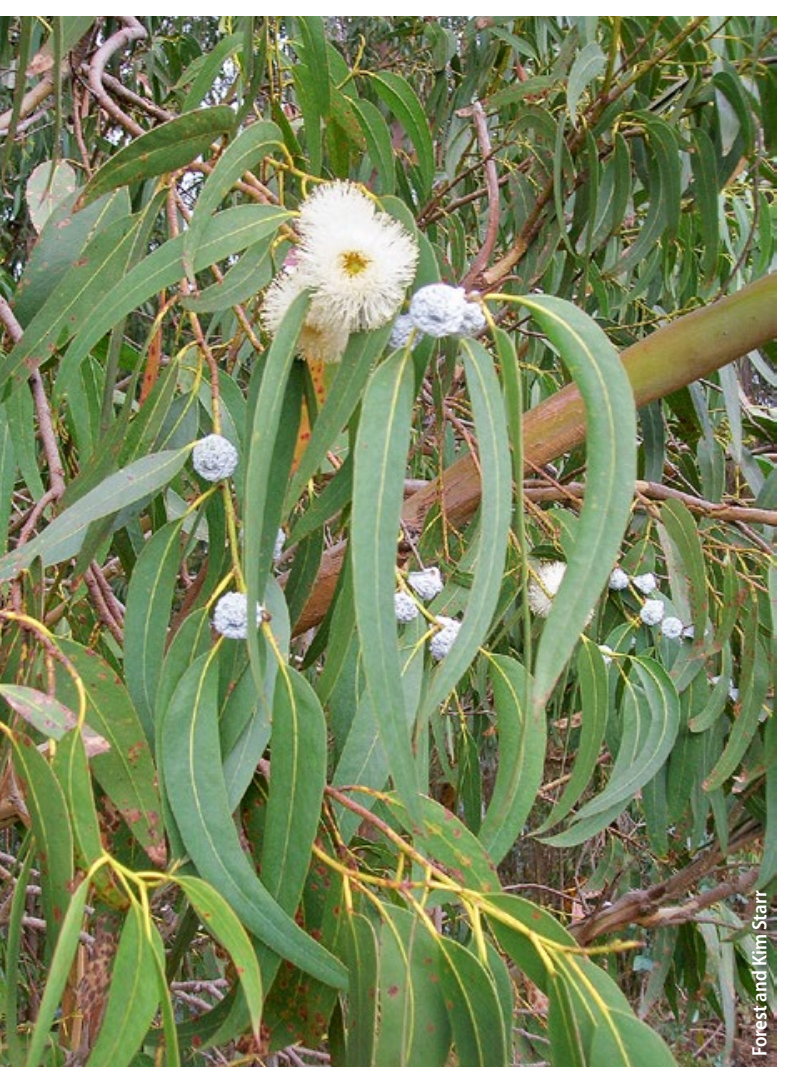

2011). Sax (2002) found that species richness was nearly identical for invertebrates, amphibians and birds in native forests and blue gum plantations, although rodents had significantly more species in native forests; moreover, species composition was different between the two forest types for all groups. Many birds, mammals and invertebrates utilize blue gum plantations at some point, although there is no consistent trend across all species for relative use of blue gum as compared with native forests (LSA Associates 2009; Rejmánek and Richardson 2011).

Macroinvertebrate species diversity did not differ between blue gum and native vegetation in riparian areas in California (Lacan et al. 2010).

Impacts on avifauna are mixed, although there is little experimental or observational information available. At an Elkhorn Slough Coastal Training Program Eucalyptus workshop, Suddjian (2004) stated that habitat quality of blue gum depends on many factors, including tree size, stand density, canopy closure, understory development and type of surrounding habitat. Compared with dense, homogeneous blue gum stands of only one age, blue gum stands of low to moderate density with mixed age structure in proximity to native woodland habitat and water provide the highest habitat value. In the Monterey Bay region, over 90 birds make regular use of blue gum habitat, although many species that nest in blue gum appear to do so at lower densities than in native habitats. More specifically, the decay-resistant wood of blue gum offers limited opportunities for nesting to woodpeckers and birds that excavate their own holes. Birds that glean insects from foliage are also present at notably lower densities in blue gum stands (Suddjian 2004).

Some bird species nest preferentially in blue gum compared with native trees, possibly due to blue gum's tall growth patterns and large limbs. In Santa Cruz County, great blue herons, great egrets and double-crested cormorants only nest in blue gum, while $85 \%$ of red-shouldered and red-tailed hawk nests were found in blue gum (Suddjian 2004). However, Suddjian also noted that while some birds use blue gum stands more than native stands, blue gum plantations do not provide equivalent habitat compared to native oak woodland and deciduous riparian vegetation for many other species. Some avifauna (e.g., cavity-nesting, foliage-gleaning and ground-nesting birds) are comparatively less abundant in blue gum stands than in native habitats, and many breeding species historically represented in the oak and riparian habitats that blue gum replaced make little or no use of blue gum in the Monterey Bay region.

In Santa Clara County, Rottenborn (2000) found that red-shouldered hawks nesting in blue gum and other nonnative tree species had higher fitness due to nonnatives' better stability and cover than that of native trees. In contrast, Williams (2002) stated that while native birds do use blue gum groves, species diversity drops by at least 70\%. Moreover, $50 \%$ of the Anna's hummingbird nests in blue gum were shaken out by the wind, while only $10 \%$ of nests were destroyed by wind in native trees. The presence of nonnative blue gum may also alter migratory bird patterns, as rare wintering species are attracted to the blue gum food sources (Suddjian 2004). To our knowledge, no studies have been conducted to determine whether this had a positive or negative impact on rare bird populations.

Suddjian (2004) reported that when birds feed among flowers of blue gum, the feathers on their faces become covered with black pitch-like residue (often incorrectly called "gum") from flower nectar, resulting in feather loss and plugging of nostrils or bills that theoretically may prevent breathing or feeding. Articles published in the Point Reyes Bird Observatory newsletter (Stallcup 1997) and Audubon magazine (Williams 2002) also implicated blue gum in mortality of North American bird species feeding amid blue gum flowers. However, Suddjian's (2004) observations revealed little evidence of deaths among birds due to plugged beaks or nostrils. Nevertheless, Williams (2002) noted experienced bird watchers had reported finding hundreds of moribund warblers with blue gum nectar covering their faces, as well as Townsend's warblers, yellow-rumped warblers, ruby-crowned kinglets, Anna's and Allen's hummingbirds, and Bullock's orioles. Suddjian (2004) suggested that more research is needed in this area due to ambiguities in observations and a lack of rigorously documented evidence of deaths due to blue gum flower nectar. 
Impacts on arthropods are also mixed: Fork (2004) showed that abundance of Diptera (flies) was higher in blue gum plantations as compared with oak woodlands, but that Coleoptera (beetles) abundance was higher in oak woodlands than in blue gum groves. Overall, order richness, total abundance and diversity of arthropods were not significantly different between oak woodland and blue gum habitats (i.e., they were either equally rare in both habitats, or equally abundant in both habitats [Fork 2004; Sax 2002]).

Blue gum is a major source of nectar and pollen for honeybees, as well as an important overwintering site for monarch butterflies (Rejmánek and Richardson 2011). Monarch butterflies may utilize nonnative habitat preferentially over native habitats (Meade 1999; Oberhauser et al. 2001; Pleasants and Oberhauser 2012); however, historical records suggest that monarch butterflies clustered on native trees prior to the introduction of blue gum (Riley and Bush 1882; Shepardson 1914). Moreover, an observational study in mixed stands (native trees mixed with blue gum) showed that monarch butterflies did not consistently cluster preferentially on blue gum, and at times, preferred native trees in some seasons and locations. For example, during mid-season overwintering ( December 31 in California) when habitat conditions are generally the least favorable for monarch butterflies, they are likely to express a preference for the most favorable microclimate. It was during this sensitive time that monarchs clustered disproportionately on native trees. Planting of additional native conifers, rather than removal of blue gum (which could reduce total habitat), may provide additional beneficial microhabitat conditions for monarch butterflies (Griffiths and Villablanca 2013).

Overall, blue gum impacts on plant and animal abundance and diversity are mixed, and target species should be managed accordingly, depending on the potential positive or negative impacts that blue gum presence or removal may have on their populations and behaviors.

\section{Blue gum spread and removal}

Blue gum is no longer widely sold or planted in California, and only one California nursery was identified that reportedly sells seeds (Dave's Garden 2014).
A Cal-HIP PlantRight survey of California nurseries indicated that few nurseries continue to sell blue gum $(<1 \%)$. Thus, retailers, growers and landscaping professionals have largely phased blue gum out of California's garden center supply chain, and replaced the species with noninvasive alternatives (Cal-HIP 2011).

CalWeedMapper (2014) allows landowners and managers to report on the status (spreading; spreading or decreasing with management; eradicated) and occurrence of blue gum in the state, and these are reported at a resolution of USGS 7.5-minute quadrangles, or approximately 8-mile $\times 6$-mile areas. This may not account for duplicate reports or naturally decreasing populations. At the time of this review, of the approximately 250 reported occurrences, about 100 were spreading (all of which occurred along the coast and coastal ranges). Of these, eight were documented as spreading with management, 18 were decreasing with management, 52 required verification of occurrence, and 30 required verification of the species identification. Including those requiring occurrence or species verification, approximately 150 did not indicate a trend in spread.

While total cover may be increasing, decreasing or remaining stable at different sites, it is possible there may be no overall change in cover statewide (Cal-IPC 2015) even without management.

Climate change may also influence blue gum cover. In California, climatematching models estimate that blue gum already exists in the regions with the most suitable climate (Calflora 2014). CalWeedMapper (2014) climate-matching reports predict a considerable increase in the suitable range for blue glum along the northern coast of California by 2050 . However, the climate-matching program does not have the capability to predict acres of potential invasion. In addition, climate-matching, in itself, does not mean that blue gum will occupy all these suitable climatic areas, as other plant characteristics, including viable seed, germination rates, seedling competition and survival all play a role in its potential spread.

In most cases, establishment of new populations in California wildlands is dependent on proximity to previously planted or otherwise established, seed-producing stands. Ritter and Yost
(2012) noted that blue gum of the same genotype can be invasive in some areas, while rarely reproducing in others. Thus, invasiveness does not appear to be related to genotypic variability, but rather environmental conditions, particularly reliable access to water. In the Central Valley, where blue gums were cultivated as a source of fuel, timber and windbreaks, they do not receive enough moisture to propagate from seed (HEAR 2007) and, as such, spread into wildlands is generally rare. Under ideal conditions where moisture is not limited, once a tree matures it can produce a large number of progeny in a few years, doubling stand area within 10 years, or spreading at a rate of 10 to 20 feet ( 3 to $6 \mathrm{~m}$ ) in diameter per year (Boyd 1997; Esser 1993).

Coastal California - and in particular, Sonoma, Monterey and Humboldt counties - is most at risk for the continued spread of blue gum. Observations by land managers and agency personnel (Tim Hyland and Vince Cicero, California State Parks, personal communication, 2014) indicate blue gum has invaded disturbed coastal prairie and willow riparian corridors at Natural Bridges State Park in Santa Cruz, and Montaña de Oro State Park in Los Osos, respectively. Aerial photos from Humboldt State University (Bicknell 1990) from 1949 (original plantation established in 1907 to 1908) showed seven species of eucalypts covering 119 acres (48 ha). By 1989, the grove had expanded to 181 acres (73 ha), of which blue gum covered 108 acres (43 ha). Overall, the area covered by all Eucalyptus species increased by $52 \%$ between 1908 and 1989. Van Dyke (2004) reported a $50 \%$ to $400 \%$ increase in blue gum stand size between 1930 and 2001 across six sites in coastal California, although one location experienced an initial increase in the first 25 years and remained stable thereafter.

\section{Research needs}

Much research has been conducted on the commercial production of blue gum in California and international production for timber and other consumptive purposes (e.g., see Standiford and Ledig 1983). However, to guide future management, observational and experimental research is still needed on some of the basic impacts of blue gum (or other Eucalyptus species) on abiotic conditions or other trophic levels. 
While Davidson (1993) pointed out that controlled, replicated and realistic experiments testing allelopathy are few and conclusions remain tenuous, he also indicated that trees should probably not be grown in low rainfall areas (15.75 inches/year, or $<400$ millimeters) due to the risk for adverse effects from allelopathy and competition for water, especially when soils are coarse textured and nutrient poor. On the other hand, plantings in areas with higher rainfall or reliable summer fog are also more likely to exhibit invasive tendencies than those in drier areas and are therefore a concern, even if allelopathy is not an issue in these regions. Continued research under local conditions is needed to test the impact of natural levels of potentially allelopathic compounds in the soil and litter layer on growth of other nonnative naturalized and native plants at different moisture levels.

Suddjian (2004) indicated that research is needed to evaluate the impacts on birds that feed among blue gum flowers. At the very least, a systematic observational study should be conducted to investigate the occurrence and extent of nectar on feathers and beaks and determine if this has a detrimental effect on fitness and survival. Further information is also needed regarding the avian use of blue gum forests relative to native vegetation. As many bird populations and behaviors are at risk, the implications of blue gum spread or removal in areas of concern would be particularly helpful to land managers.

Some reproductive characteristics of blue gum are unclear as well. The number of seeds produced per square meter each year has not been clearly assessed. How quickly and under what circumstances vegetative reproduction occurs in California across a variety of different habitats needs to be clarified. Further research should elucidate whether or not blue gum reliably produces seed crops each year, and under what climatic conditions seeds are produced, so that regional weed risk assessments are more accurate in predicting potential invasiveness.

In addition, it is not known exactly where and to what extent populations of blue gum are naturally decreasing, increasing or remaining stable. While CalWeedMapper (2014) provides reports of blue gum occurrence, data regarding the status of these populations (rate of spread or decrease, if populations are

\section{Management implications}

Management of blue gum must be site and context specific and goal oriented, requiring sufficient time be spent on clarifying the desired outcomes of vegetation management, compiling information regarding climate and native plant and animal communities, and considering social factors. For example, while blue gum is a nonnative plant that in some cases can be particularly invasive or hazardous, eradication of blue gum populations is not always appropriate. Where current plantings may be desirable for alternative monarch butterfly habitat, for instance, land managers should carefully consider

\section{While blue gum is a nonnative plant that in some cases can be particularly invasive or hazardous, eradication of blue gum populations is not always appropriate.}

naturally spreading or decreasing) is insufficient to determine the actual rate of spread or area covered locally, regionally or statewide.

Finally, while weed risk assessments have been conducted on blue gum for the state of California, these assessments are not regional or context specific, do not account for the great variety of ecoregions within the state, and do not incorporate management goals, safety considerations or species-specific concerns or benefits. Local climate is particularly influential in determining whether or not blue gum is likely to spread, or will be difficult to either eradicate or maintain. Thus, assessments that allow for area-specific climatic information would be useful in guiding management efforts by state parks, conservation-based institutions and city planning organizations. potential outcomes on monarch populations. However, caution should be simultaneously exercised, because monarch butterflies overwinter in coastal regions (Marriot 1997) where blue gum is more likely to spread naturally and become invasive (Ritter and Yost 2012). In many areas, blue gum is considered an aesthetically desirable landscape component, and these cultural considerations should be accounted for when determining best methods for ensuring community safety (e.g., risks associated with blue gum include fire hazards and falling limbs). CA

K.M. Wolf is Graduate Student Researcher and J.M. DiTomaso is UC ANR Cooperative Extension Specialist and Professor in the Department of Plant Sciences at UC Davis.

\section{References}

Aggangan RG, O'Connell AT, McGrath JF, Dell B. 1999. The effects of Eucalyptus globulus leaf litter on C and N mineralization in soils from pasture and native forest. Soil Biol Biochem 31(11):1481-7. doi:10.1016/S00380717(99)00052-8.

Baldwin B, Goldman DH (eds.). 2012. The Jepson manual Vascular plants of California (2nd ed.). Berkeley, CA: UC Press. $1568 p$

Bean C, Russo MJ. 1989. Elemental stewardship abstract for Eucalyptus globulus (revised). Arlington, VA: The Nature Conservancy. www.invasive.org/gist/esadocs/documnts/ eucaglo.pdf (accessed March 24, 2014).
Bean C, Russo MJ. 2014. Bugwood Wiki. Eucalyptus globulus. Tifton, GA: University of Georgia. http://wiki. bugwood.org/Eucalyptus_globulus (accessed March 22, 2014).

Bicknell SH. 1990. Montana de Oro State Park presettlement vegetation mapping and ecological status of Eucalyptus: Final report. Humboldt State University, CA. 91 p.

Bossard CC, Randall JM, Hoshovsky MC. 2000. Invasive plants of California's wildlands. Berkeley, CA: UC Press. $360 \mathrm{p}$.

Boyd D. 1997. Eucalyptus removal on Angel Island. Novato, CA: California State Parks. www.cal-ipc.org/symposia/archive/pdf/1997_symposium_proceedings1936.pdf (accessed March 25, 2014)
Brooker MIH. 2000. A new classification of the genus Eucalyptus L'Hér. (Myrtaceae). Aust Syst Bot 13(1):79-148.

Burns RM, Honkala BH (tech. coords.). 1990. Silvics of North America, Vol. 2: Hardwoods. Agriculture Handbook 654. Washington, DC: US Department of Agriculture, Forest Service. 877 p.

Butterfield HM. 1935. The introduction of Eucalyptus into California. Madroño 3(4):149-54.

Calflora. 2014. The Calflora database. Berkeley, CA. www. calflora.org (accessed March 22, 2014).

[Cal-HIP] California Horticultural Invasives Prevention. 2011. PlantRight: Invasive plants in your region. San Francisco, CA: California Horticultural Invasives Prevention. www.plantright.org/regions/south-coast (accessed April 22, 2014). 
[Cal-IPC] California Invasive Plant Council. 2003. Criteria for categorizing invasive non-native plants that threaten wildlands. www.cal-ipc.org/ip/inventory/pdf/Criteria.pdf (accessed November 17, 2015).

Cal-IPC. 2015. Cal-IPC plant assessment form: Eucalyptus globulus. Berkeley, CA: California Invasive Plant Council. www.cal-ipc.org/paf/site/paf/538 (accessed March 15, 2014).

[CAPRC] City of Albany Parks and Recreation Commission. 2011. Preliminary draft vegetation management plan. Albany Hill and Creekside Park. www.albanyca.org/ index.aspx?page=1014 (accessed March 31, 2014).

[CPCS] California Poison Control System. 2009. Know your plants. San Francisco, CA: UC San Francisco, Department of Clinical Pharmacy. www.calpoison.org/hcp/KNOW\%20 YOUR\%20PLANTS-plant\%20list\%20for\%20CPCS\%2009B. pdf (accessed December 9, 2014).

CalWeedMapper. 2014. Eucalyptus globulus. Berkeley, CA: California Invasive Plant Council. http://calweedmapper. cal-ipc.org (accessed March 28, 2014).

Dave's Garden. 2014. Eucalyptus globulus. http://davesgarden.com/guides/pf/go/62576/ (accessed November 17, 2015).

Davidson J. 1993. Ecological aspects of Eucalyptus plantations. In: White K, Ball J. Kashio M (eds.). Proceedings Regional Expert Consultation on Eucalyptus, Oct. 4-8, 1993, Volume 1. Bangkok, Thailand: Food and Agriculture Organization, Regional Office for Asia and the Pacific. www.fao.org/docrep/005/ac777e/ac777e06.htm (accessed December 9, 2014).

Del Moral R, Muller CH. 1969. Fog drip: A mechanism of toxin transport from Eucalyptus globulus. B Torrey Bot Club 96(4):467-75. www.jstor.org/stable/2484065.

Dickinson KJM, Kirkpatrick JB. 1985. The flammability and energy content of some important plant species and fue components in the forests of southeastern Tasmania. J Biogeogr 12(2):121-34. www.jstor.org/stable/2844836. DiTomaso JM, Healy EA. 2007. Tasmanian blue gum. In: Weeds of California and other western states (Vol. 2: Geraniaceae-Zygophllaceae). Oakland, CA: Regents of the University of California. p 951-4.

Esser L. 1993. Eucalyptus globulus. In: Fire Effects Information System. US Department of Agriculture, Forest Service, Rocky Mountain Research Station, Fire Sciences Laboratory. www.fs.fed.us/database/feis/plants/tree/ eucglo/all.html (accessed March 24, 2014).

Farmer J. 2013. Trees in paradise: A California history. New York: W.W. Norton \& Company, Inc. 552 p.

[FEMA] Federal Emergency Management Agency. 2013. East Bay Hills hazardous fire risk reduction environmental impact statement. Washington, DC: Federal Emergency Management Agency, U.S. Department of Homeland Security. http://ebheis.cdmims.com/Documents.aspx (accessed March 24, 2014).

National Tropical Botanical Garden. 2015. Flora of the Hawaiian Islands. Washington DC: Smithsonian National Museum of Natural History. http://botany.si.edu/pacificislandbiodiversity/hawaiianflora/ (accessed August 17, 2015).

Florence RG. 1996. Ecology and silviculture of eucalyptus forests. Victoria, Australia: CSIRO Publishing. 413 p.

Fork S. 2004. Arthropod diversity in native and exotic woodlands. Ecology and impacts of blue gum eucalyptus in coastal California, June 3, 2004. Moss Landing, CA: Moss Landing Marine Laboratories. www.elkhornsloughctp.org/uploads/files/1108146921S.\%20Fork\%20 Presentation.pdf (accessed April 28, 2014).

Griffiths J, Villablanca F. 2013. Management of monarch butterfly (Danaus plexippus) overwintering habitat: Recommendations based on patterns of tree use. Monarch Alert, California Polytechnic State University, San Luis Obispo, CA. http://monarchalert.calpoly.edu/pdf/ Griffiths\%20and\%20Villablanca\%202013\%20Eucalyptus\%20White\%20Paper.pdf (accessed April 23, 2014).
Groenendaal GM. 1983. Eucalyptus helped solve a timber problem. In: Proceedings of the Workshop on Eucalyptus in California, June 14-16, 1983. Sacramento, CA. P 1853-80.

HEAR. 2007. Eucalyptus globulus. Hawaiian Ecosystems at Risk project: Invasive species information for Hawaii and the Pacific, Pacific Basin information node. www.hear.org/ pier/wra/pacific/eucalyptus_globulus_htmlwra.htm (accessed March 22, 2014).

Jones C. 2009. UC Berkeley's Eucalyptus removal plan stalled. San Francisco, CA: SFGate. www.sfgate.com/ bayarea/article/UC-Berkeley-s-eucalyptus-removal-planstalled-3252677.php (accessed March 25, 2014).

Lacan I, Resh VH, McBride JR. 2010. Similar breakdown rates and benthic macroinvertebrate assemblages on native and Eucalyptus globulus leaf litter in Californian streams. Freshwater Biol 55(4):739-52. doi:10.1111/j.13652427.2009.02312.x.

Lange RT, Reynolds T. 1981. Halo effects in native vegetation. T Roy Soc South Aust 105(4):213-4.

LSA Associates. 2009. Wildfire hazard reduction and resource management plan. V. Vegetation management plan. Oakland, CA: East Bay Regional Park District. www. ebparks.org/Assets/files/fireplan/ebrpd_whrrm_plan/5VegMan.pdf (accessed March 23, 2014).

Marriot D. 1997. Where to see the monarchs in California: Twenty-five selected sites. Vista, CA: California Monarch Studies, Inc. www.monarchwatch.org/download/pdf/ where.pdf (accessed December 10, 2014).

May FE, Ash JE. 1990. An assessment of the allelopathic potential of Eucalyptus. Aust J Bot 38(3):245-54. doi:10.1071/BT9900245

Meade DE. 1999. Monarch butterfly overwintering sites in Santa Barbara County, California. Santa Barbara, CA County of Santa Barbara Planning and Development Department. $114 \mathrm{p}$

MetcalfW. 1924. Growth of Eucalyptus in California plantations. Bulletin No. 380. Berkeley, CA: University of California Publications. $64 \mathrm{p}$

Molina A, Reigosa MJ, Carballeira A. 1991. Release of allelochemical agents from litter, throughfall, and topsoil in plantations of Eucalyptus globulus in Spain. J Chem Ecol 17(1):147-60. doi:10.1007/BF00994428.

[NPS] National Park Service. 2006. Eucalyptus. Point Reyes Station, CA: San Francisco Bay Area National Parks, Fire Education Office. www.nps.gov/pore/learn/management/upload/firemanagement_fireeducation_newsletter_eucalyptus.pdf (accessed November 17, 2015).

Oberhauser KS, Prysby MD, Mattila HR, et al. 2001. Tempo ral and spatial overlap between monarch larvae and corn pollen. P Natl Acad Sci USA 98(21):11913-8. doi:10.1073/ pnas.211234298.

Pleasants JM, Oberhauser KS. 2012. Milkweed loss in agricultural fields because of herbicide use: Effect on the monarch butterfly population. Insect Conserv Diver 6(2):135-44. doi:10.1111/j.1752-4598.2012.00196.x.

Pryor LD. 1976. The biology of eucalypts. London: Edward Arnold. 82 p.

Radosevich SR, Holt JS, Ghersa CM. 2007. Ecology of weeds and invasive plants: Relationship to agriculture and natural resource management. Hoboken, NJ: John Wiley \& Sons. $454 \mathrm{p}$.

Rejmánek M, Richardson DM. 2011. Eucalypts. In: Simberloff D, Rejmánek M (eds.). Encyclopedia of biologica invasions. Berkeley, CA: UC Press. p 203-9.

Riley CV, Bush AE. 1882. The butterfly trees of Monterey again. Am Nat 16:64

Ritter M, Yost J. 2009. Diversity, reproduction, and potential for invasiveness of Eucalyptus in California. Madroño 56(3):155-67. doi:10.3120/0024-9637-56.3.155

Ritter M, Yost J. 2012. Bluegum weediness in California is not genetically based (abstract). California Native Plant Society conference, January 10-14, 2012. San Diego, CA. www.cnps.org/cnps/conservation/conference/2012/ pdf/cnps2012-presentation_abstracts.pdf (accessed 24 March 2014)
Rottenborn SC. 2000. Nest-site selection and reproductive success of urban red shouldered hawks in central California. J Raptor Res 34(1):18-25.

Russell WH, McBride JR. 2002. Vegetation change and fire hazard in the San Francisco Bay Area open spaces. In: Morales T, Morales M (eds.). Proceedings of the California's 2001 wildfire conference: Ten years after the East Bay Hills fire; October 10-12, 2001. Oakland, CA. Technical Report 35.01.462. Richmond, CA: UC Forest Products Laboratory. p. 27-38. www.diablofiresafe.org/pdf/proceedings2001.pdf (accessed March 24, 2014).

Santos RL. 1997. The Eucalyptus of California: Seeds of Good or Seeds of Evil? Denair, CA: Alley-Cass Publications. 165 p.

Sax D. 2002. Equal diversity in disparate species assemblages: A comparison of native and exotic woodlands in California. Global Ecol Biogeogr 11(1):49-57. doi:10.1046/ .1466-822X.2001.00262.x

[SFRP] San Francisco Recreation and Parks 2006. Significant natural resource areas management plan. San Francisco, CA: San Francisco Recreation and Parks. http:// sfrecpark.org/parks-open-spaces/natural-areas-program/ significant-natural-resource-areas-management-plan/ snramp/ (accessed March 3, 2014).

Shepardson L. 1914. The Butterfly Trees. San Francisco, CA: The James H. Barry Company. 44 p.

Skolmen RG. 1983. Growth and yield of some eucalypts of interest to California. In: Gen. Tech. Rep. PSW 69. Berkeley, CA: Pacific Southwest Forest and Range Experiment Station, Forest Service, US Department of Agriculture. p 49-57.

Stallcup R. 1997. Deadly Eucalyptus. Observer No. 108. Point Reyes Bird Observatory. www.prbo.org/OBSERVER/ Observer108/Focus 108.2.html (accessed March 25, 2014).

Standiford RB, Ledig FT. 1983. Economic evaluation of eucalypt energy plantations. In: Standiford RB, Ledig FT (tech. coords.). Proceedings of the Workshop on Eucalyptus in California, June 14-16, 1983. Sacramento, CA. p 42-8. http://gis.fs.fed.us/psw/publications/documents/ psw gtr069/psw_gtr069_03 standiford.pdf (accessed April 14, 2014).

Suddjian DL. 2004. Birds and Eucalyptus on the central coast of California: A love-hate relationship. www.elkhornsloughctp.org/uploads/files/1 108147180Suddjianunpublished\%20conference\%20notes.pdf (accessed March 24, 2014)

[UC Regents] Regents of the University of California. 2014. Consortium of California herbaria: County-level distribution results. Berkeley, CA: Regents of the University of California. http://ucjeps.berkeley.edu/cgi-bin/ get_smasch_county.pl?taxon_id=25266 (accessed December 9, 2014)

[USDA PLANTS] United States Department of Agriculture PLANTS Database. 2015. Eucalyptus globulus Labill. Tasmanian bluegum. http://plants.usda.gov/core/ profile?symbol=EUGL (accessed January 14, 2015).

Van Dyke E. 2004. Blue gum eucalyptus in the Elkhorn watershed: 1930 - present. Ecology and impacts of blue gum eucalyptus in coastal California, June 3, 2004. Moss Landing, CA: Moss Landing Marine Laboratories. www.elkhornsloughctp.org/uploads/ files/1108143446Vandyke\%20Presentation.pdf (accessed April 28, 2014).

Watson K. 2000. The effect of Eucalyptus and oak leaf extracts on California native plants. Master's thesis, UC Berkeley College of Natural Resources. nature.berkeley. edu/classes/es196/projects/2000final/watson.pdf (accessed March 31, 2014).

Williams T. 2002. America's largest weed. Audubon Magazine Jan./Feb. 2002. archive.audubonmagazine.org/ incite/incite0201.html (accessed March 31, 2014). 